\title{
Colocação literária e estrutura da bênção aarônica (Nm 6,22-27)
}

\author{
Literary placement and structure of the Aaronic blessing \\ (Num 6,22-27)
}

Ildo Perondi

Fabrizio Zandonadi Catenassi

\section{Resumo}

O artigo tem como objetivo a discussão da colocação literária (Sitz in der Literatur) da bênção aarônica $(\mathrm{Nm}$ 6,22-27) e da estrutura da perícope, especialmente quando comparada com textos semelhantes, bíblicos e extrabíblicos. Nossa proposta sobre a colocação literária foi influenciada particularmente pela narratologia, de forma que a bênção foi entendida como uma conclusão lógica dos caps. $1-5$, os quais proporcionam uma visão triunfante da organização cúltico-militar dos israelitas no contexto da preparação para a marcha rumo a Canaã. Trata-se de uma garantia da presença de YHWH junto a seu povo a partir da mediação sacerdotal. O estudo das fórmulas semelhantes a $\mathrm{Nm}$ 6,22-27 permitiu afirmar que é muito antiga e foi bem conservada nos amuletos de Ketef Hinnom. Sendo assim, a versão consignada em Números deve ter inspirado outros textos bíblicos semelhantes, particularmente, dos salmos. Contudo, a estrutura presente no quarto livro do Pentateuco é particular e notável. As técnicas de emolduramento, paralelismos e acomodação gradativa de palavras, sílabas e consoantes dão ao texto um efeito litúrgico e popular poderoso. Ainda que a versão grega antiga proponha uma alteração dessa estrutura, nosso estudo destacou que a harmonia da versão final do Texto Massorético é inegável e irretocável.

Palavras-chave: Pentateuco. Números. Bênção aarônica. Sitz in der Literatur. Estrutura. 


\section{Abstract}

The article has as objective to discuss the literary placement (Sitz in der Literatur) of the Aaronic blessing (Num 6,22-27) and the structure of the pericope, especially when compared with similar texts, biblical and extrabiblical. Our proposal on the literary placement was particularly influenced by narratology, so that the blessing was understood as a logical conclusion from chaps. 1-5, which provide a triumphant vision of the Israelites' cultic-military organization in the context of preparation for the march to Canaan. It is a guarantee of YHWH's presence with his people through priestly mediation. The study of formulas similar to Num 6,22-27 allows us to say that it is very old and was well preserved in Ketef Hinnom's amulets. Thus, a version recorded in Numbers must have inspired other similar biblical texts, particularly the psalms. However, the structure present in the fourth book of the Pentateuch is particular and remarkable. The framing techniques, parallelisms and gradual accommodation of words, syllables and consonants give to the text a powerful effect, liturgical and popular. Although the ancient Greek version proposes an alteration of this structure, our study has highlighted that the final version of the Masoretic Text is undeniable and untouchable.

Keywords: Pentateuch. Numbers. Aaronic blessing. Sitz in der Literatur. Structure.

\section{Introdução}

Orígenes defendia que se o livro de Números fosse lido a uma alma doente e débil, ela pensaria que seu conteúdo não é um remédio para sua enfermidade e que não lhe servia a nada. ${ }^{1}$ É bem verdade que o texto nos leva a testemunhar Israel no deserto, entre normas de pureza, conflitos e murmurações que não são diretamente agradáveis ao leitor pouco familiarizado com a Bíblia. Mas o juízo de Orígenes certamente não pode ser aplicado à bênção aarônica presente em Nm 6,22-27: provavelmente, é o texto mais conhecido de Números, escrito com grande senso artístico e litúrgico, muito importante para o Israel do Antigo Testamento (AT).

\footnotetext{
${ }^{1}$ ORÍGENES, Hom. Num. 27,1.
} 
Para Ibn Ezra, ${ }^{2}$ essa bênção seria a expressão textual daquela recitada por Aarão após a consagração do Tabernáculo (Lv 9,21-22), o que, de fato, estaria bem adequado à lógica de Levítico, como apontam grande parte dos comentadores de Números. ${ }^{3}$ Nesse sentido, causa estranheza que a bênção esteja localizada em Números 6, após uma legislação sobre o nazireato (Nm 6,1-21). À primeira vista, parece uma amostra da diversidade de tipo de material e gêneros literários que aparecem ao longo do livro e dificultam a identificação de um projeto literário claro que costure seus textos. Contudo, estudos literários em perícopes específicas de Números têm apontado uma construção bem arquitetada da obra, ${ }^{4}$ o que justifica a discussão do Sitz in der Literatur da oração de Nm 6,22-27.

Em relação à estrutura da bênção aarônica, $M$. Noth indicava que seu texto tinha paralelos bíblicos de forma e conteúdo, apesar de não apresentar uma simetria métrica. ${ }^{5}$ Contudo, o texto parece organizado com esmero quando se compara a outras orações similares. Por sua importância, partes da bênção aarônica aparecem em uma série de textos da Bíblia judaica, especialmente no livro de salmos, onde podem ser encontrados fragmentos da oração. Também fora da Bíblia a oração é replicada de maneira quase idêntica em dois amuletos encontrados em Ketef Hinnom. Nesse sentido, uma análise comparativa pode destacar o arranjo literário ímpar que se constrói na versão da oração em Números.

Nesse sentido, o presente artigo tem como objetivo a discussão do Sitz in der Literatur da bênção aarônica (Nm 6,22-27), bem como da estrutura da perícope, especialmente quando comparada com textos semelhantes, bíblicos e extra-bíblicos.

\section{Tradução e crítica textual}

Apresentamos a seguir o texto hebraico de $\mathrm{Nm} \mathrm{6,22-27}$ a partir da $5^{\mathrm{a}}$

\footnotetext{
${ }^{2}$ EZRA, I. apud MILGROM, J. Numbers, p. 51.

${ }^{3}$ P. ex.: BUDD, P. J., Numbers, p. 76; GRAY, G. B., A critical and exegetical commentary on Numbers, p. 71; LEVINE, B. A., Numbers 1-20, p. 23-244.

${ }^{4}$ CATENASSI, F. Z., Análise narrativa da transgressão em Cades (Números 13-14), p. 32-33.

${ }^{5}$ NOTH, M., Numbers, p. 58. Em contrapartida, Há importantes notas sobre o arranjo narrativo em Números, presentes em comentadores clássicos como Milgrom e Levine, que destacam a fineza de estruturas literárias e da poética que compõe a retórica do livro (MILGROM, J., Numbers, p. xxii-xxxi; LEVINE, B. A., Numbers 1-20, p. 72-82). Seria de se esperar, assim, que uma oração de destaque como a benção aarônica fosse esmeradamente construída, com recursos poéticos finos que facilitassem especialmente seu uso litúrgico.
} 
edição da Bíblia Hebraica Stuttgartensia (BHS), com a correspondente segmentação e tradução, seguindo o princípio da correspondência formal. Em seguida, discutimos as principais variantes textuais, especialmente as opções da Septuaginta (LXX) e da Vulgata. ${ }^{6}$

\begin{tabular}{|c|c|c|}
\hline Versículo & Texto hebraico & Tradução \\
\hline 22 & 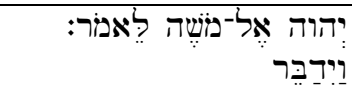 & $\begin{array}{l}\text { E falou o YHWH a Moisés, } \\
\text { dizendo }^{7}\end{array}$ \\
\hline $23 \mathrm{a}$ & 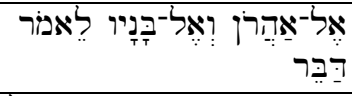 & $\begin{array}{l}\text { "Fala a Aarão e aos seus filhos, } \\
\text { dizendo: }\end{array}$ \\
\hline $23 b$ & 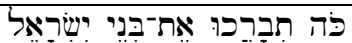 & Assim abençoareis os filhos de Israel, \\
\hline $23 \mathrm{c}$ & אומוֹר לָהֶם: 0 & dizendo a eles: \\
\hline $24 a$ & 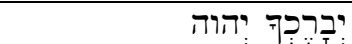 & 'YHWH te abençoe \\
\hline $24 b$ & 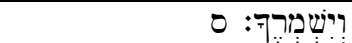 & e te guarde. \\
\hline $25 a$ & 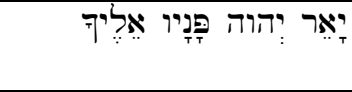 & $\begin{array}{l}\text { YHWH faça resplandecer o seu } \\
\text { rosto em direção a ti }\end{array}$ \\
\hline $25 \mathrm{~b}$ & 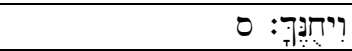 & e te seja bondoso. \\
\hline $26 a$ & 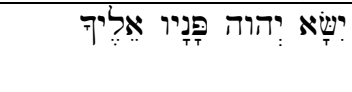 & $\begin{array}{l}\text { YHWH dirija o seu rosto em } \\
\text { direção a ti }\end{array}$ \\
\hline $26 \mathrm{~b}$ & וִישׁם לְך שָׁלוֹם: 0 & e te dê paz'. \\
\hline $27 \mathrm{a}$ & 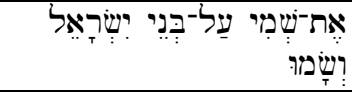 & $\begin{array}{l}\text { E colocarão o meu nome sobre os } \\
\text { filhos de Israel, }\end{array}$ \\
\hline $27 \mathrm{~b}$ & 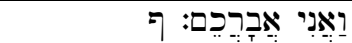 & e eu os abençoarei”. \\
\hline
\end{tabular}

${ }^{6}$ Utilizamos as seguintes versões: ELLIGER, K.; RUDOLPH, W. (Eds.), Biblia Hebraica Stuttgartensia; WEVERS, J. W. (Ed.), Septuaginta; WEBER, R. (Ed.). Biblia Sacra iuxta Vulgatam versionem. A NOVA Vulgata Bibliorum Sacrorum Editio faz algumas modificações no texto de $\mathrm{Nm}$ 6,22-27, tornando-o mais atual, mais próximo ao texto hebraico e mais fácil de ser lido do que aquele da Vulgata antiga: coloca a pontuação, inicia as frases sempre com maiúscula, acrescenta a conjunção que nos versículos 22 e 27, os nomes próprios de Moisés e de Israel vêm escritos de uma forma mais atualizada.

7 Tomou-se por norma não considerar segmentos diferentes as orações subordinadas formadas pelo infinitivo ליאמר, mas separar unidades que exercem uma função completa: apostos, elementos em listas, entre outros (STENGER apud SILVA, C. M. D., Metodologia de exegese bíblica, p. 85). Esse infinitivo constructo hebraico foi traduzido seguindo a LXX, que o relaciona como particípio presente. 
No v. 22, a LXX traduz o tetragrama como kúpıos, como faz de maneira geral com o nome divino nos livros dos Números e Levítico; em alguns casos nos outros livros do Pentateuco (Gênesis, Êxodo e Deuteronômio), preferiu traduzir $\operatorname{com} \theta \in$ cós. O v. $23 \mathrm{c}$ traz a lição no qal infinito absoluto. A BHS propõe que

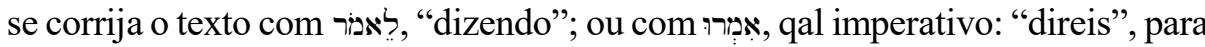
tornar a leitura do texto mais correta e fluída. A LXX traduz com o particípio $\lambda \epsilon \in \gamma o \nu \tau \epsilon \varsigma ;$ a Vulgata traz et dicetis, preferindo um futuro simples. A versão grega mais antiga, textus Graecus originalis (LXX*), propõe deslocar o versículo 27 para o final do versículo 23, como discutiremos posteriormente.

O Pentateuco Samaritano (PS) propõe a substituição de יָאר em 25a por .יִיִיר. As duas expressões são formas possíveis do hifil imperfeito 3 pms no formato jussivo do verbo אור, ambas pouco usadas no AT. A lição proposta pelo PS não aparece nunca no Pentateuco ${ }^{8}$ ou nos Livros Históricos, mas encontrase cinco vezes em outros livros do AT (Jó 41,24; S1 119,130; 139,12; Is 60,19; Ez 32,7). É verdade, porém, que a forma encontrada no Texto Massorético (TM) também é usada somente uma outra vez, no Salmo 67,2, um texto que é dependente de $\mathrm{Nm} 6,25$.

A expressão פָּנָ aparece nos vv. 25b e 26a no TM. A LXX traduziu

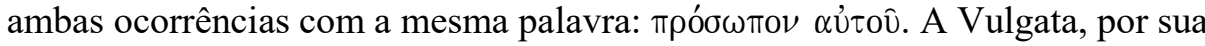
vez, preferiu usar dois sinônimos: faciem suam (v. 25b) e vultum suum (v. 26a). A opção mantém o significado do texto hebraico, porém diferenciando-se na forma. A diferença é somente de estilo: enquanto o texto hebraico gosta de repetir as expressões, o texto latino preferiu uma correção de estilo.

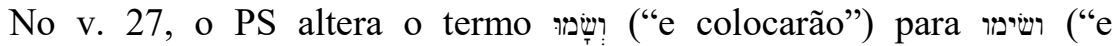
colocareis"). A mudança é significativa para interpretar a estrutura da perícope. Essa passagem do perfeito para o imperativo faz com que o PS coloque Aarão e seus filhos como interlocutores do verbo, de forma que o texto permanece como parte da bênção. Na tradição massorética, o v. 27 é a conclusão da bênção e retomada do diálogo entre Deus e Moisés.

Na tradução latina da Vulgata, o termo רִשְׁ é traduzido como invocabunt. Essa opção reproduz bem o significado do verbo ("invocar, gritar, chamar"), mas não reflete bem o sentido de que indica a ação de colocar,

\footnotetext{
${ }^{8}$ Encontra-se também יאיריר algumas vezes no AT, mas como nome próprio de pessoa masculina: "Yair" ou "Jair".
} 
depositar, assentar, fixar, impor, promulgar, entre outras. ${ }^{9} \mathrm{O}$ sentido de "colocar" se encaixa melhor: o nome de Deus devia ser posto sobre a vida do povo como uma proteção, a exemplo da nuvem que acompanhou o caminho no deserto (Ex 13,21-22).

\section{Sitz in der Literatur}

Após a proposta de tradução e análise de crítica textual, a primeira etapa de nossa discussão está relacionada à localização literária da perícope no contexto do conjunto do livro, conhecida como Sitz in der Literatur. As discussões clássicas giraram em torno da definição da bênção aarônica como um apêndice mal colocado ou da sua relação com o nazireato, como veremos a seguir.

$\mathrm{O}$ texto clássico de Gray ${ }^{10}$ é representativo dos estudiosos que defendem que a localização correta da bênção aarônica é no livro do Levítico. Após a entrada dos sacerdotes na função litúrgica, o texto narra Aarão abençoando o povo, sem indicar a fórmula usada ( $\operatorname{lv}$ 9,22-23). Essa perícope representa como uma bênção conclui bem o trabalho ritual, colocada como o cume da revelação do tabernáculo, do sistema sacrifical e do sacerdócio (Ex 25-Lv 9). ${ }^{11}$ Dessa forma, na redação final do Pentateuco, Nm 6,22-27 teria sido deslocado de Levítico, onde originalmente representaria o conteúdo da bênção proferida por Aarão, para servir como a conclusão dos materiais principalmente legislativos que se encontram de $\mathrm{Lv} 1$ a $\mathrm{Nm}$ 6. A proposta é hipotética e depende fundamentalmente das interpretações da crítica histórica e literária sobre a formação do Pentateuco.

Milgrom $^{12}$ defende que a estrutura organizacional abrangente de Números deve ser determinada particularmente a partir das conexões temáticas e verbais que ligam os materiais. Nesse sentido, a localização da bênção aarônica deve ser encontrada a partir de um olhar particular aos capítulos 5-6 do livro, compostos por leis e normas diversas, aparentemente sem unidade. Em geral, aponta-se que o único elemento que está presente em praticamente todas as perícopes desses capítulos é o papel proeminente do sacerdote em cada

\footnotetext{
${ }^{9}$ ALONSO SCHÖKEL, L., Dicionário bíblico hebraico-português, p. 638-640.

${ }^{10}$ GRAY, J. B., A critical and exegetical commentary on Numbers, p. 71.

${ }^{11}$ ASHLEY, T. R., The Book of Numbers, p. 149.

${ }^{12}$ MILGROM, J., Numbers, p. xiv.
} 
uma delas: ${ }^{13}$ ele determina a impureza ritual (5,11-13), oficia o sacrifício de reparação (5,5-8), recebe as doações do santuário (5,8-10), é responsável por executar o ordálio (5,11-31), oficia o ritual do nazireato $(6,1-21)$ e, finalmente, oferece a bênção sacerdotal (6,22-27). Sendo assim, a bênção seria uma conclusão magna da função sacerdotal.

Outra proposta para determinar o Sitz in der Literatur parte da relação que estabelece com as prescrições sobre o voto de nazireato. ${ }^{14}$ Em geral, os defensores dessa hipótese veem um nexo entre bênção e nazireu a partir dos textos de Gn 49,26 e Dt 33,16, nos quais se invoca a bênção sobre a cabeça de José "nazir dos seus irmãos". Nesse sentido, a bênção apareceria como uma resposta bondosa de Deus ao ato voluntário de consagração, feita para aquele que é separado. ${ }^{15}$ Contra essa abordagem está o fato de que o texto não restringe o raio de ação da bênção aos nazireus, mas a estende aos filhos de Israel (vv. 23b.27a), sem absolutamente nenhuma especificação.

Diante da dificuldade das duas propostas de explicação já discutidas, partimos para uma discussão da colocação literária da bênção aarônica a partir da lógica narrativa de Números. A perícope está inserida na primeira parte do livro $(1,1-10,10)$, na qual se descreve o tempo que o povo de Israel permaneceu no deserto do Sinai. Esse bloco literário inicial mostra a preparação para a partida em direção à terra prometida, reforçando a ideia de que Israel é uma comunidade santa, que se acomoda ao redor do santuário. ${ }^{16}$ Nesse sentido, os caps. 1-4 retratam o acampamento estruturado de forma que se salvaguarde a presença de YHWH em seu centro, demonstrado nas especificações para os recenseamentos das tribos, as funções dos levitas, as disposições e o resgate dos primogênitos das tribos (1-4). Os caps. 5-6 mostram as leis que protegem a pureza e a santidade das tribos, garantidas pelo afastamento dos impuros por lepra e por contato com

\footnotetext{
${ }^{13}$ KNIERIN, R. P.; COATS, G. W., Numbers, p. 33; MILGROM, J., Numbers, p. xiv.

${ }_{14}$ MANICARDI, L., La benedizione sacerdotale, Nm 6,22-27, p. 61-62; VAULX, J., Les Nombres, p. 90, 103.

${ }^{15}$ LAMADRID, A. G., Numeros, p. 47. J. de Vaulx vê a conexão entre nazireato e bênção a partir do texto de Pr 3,33b: "Ele abençoou a habitação dos justos", explicando que "se refere ao homem e à mulher que fizeram o voto de nazireato, os quais se separaram do vinho para preservar-se da trasgressão, merecem uma bênção. $O$ motivo então pelo qual a Escritura coloca a bênção sacerdotal logo depois da seção sobre o nazireato é que aquele que fez voto de nazireato obtém o privilégio de receber a bênção contida na bênção sacerdotal" (VAULX, J., Les Nombres, p. 103, tradução nossa).

${ }^{16}$ CATENASSI, F. Z., Reclamando "de barriga cheia”, p. 13.
} 
um morto $(5,1-4)$, pela falta de santidade expressa pela injustiça nas relações humanas $(5,5-31)$ e pela consagração pelo nazireato $(6,1-21)$.

Nesse sentido, a bênção de Números 6,22-27 conclui triunfalmente a preparação litúrgico-militar para a caminhada rumo a Canaã. Na lógica do livro, a bênção é uma garantia do sucesso na empreitada; mostra que o objetivo de YHWH com toda essa organização é abençoar. Isso fica evidente na rebelião generalizada acontecida na parada em Cades (Nm 14) quando, pela desobediência dos israelitas, eles sobem para a guerra sem a presença de YHWH no meio deles, resultando em uma destruição esmagadora (Nm 14,45). É uma antítese da bênção, com função pragmática: a falta de obediência tira a bênção, a guarda, o favor de Deus e a paz dos israelitas; é como se o nome de YHWH não estivesse com eles.

A bênção vem antes de uma analepse que vai do cap. 7 a 10,11, quando a marcha se inicia. Esse flashback leva o leitor para um mês antes do censo das tribos, quando a morada é construída (Ex 40), na ocasião da dedicação do altar (Lv 8). É como se o livro resgatasse os episódios que foram culminados com a bênção de Aarão em Lv 9,22-23 e mostrasse os efeitos dela até então, de forma que a generosidade das ofertas, o cuidado com a morada e o culto houvessem preparado os israelitas para a fórmula completa da bênção em Números. A revelação do conteúdo da bênção, por sua vez, demonstra que YHWH está firmemente presente junto de seu povo, garantindo todo o necessário para o início da campanha de conquista, como discutiremos nos itens a seguir.

\section{A bênção aarônica no contexto das bênçãos judaicas}

A fim de destacar a estrutura ímpar da bênção aarônica, passamos a uma comparação da fórmula da bênção com outros tipos que ocorrem em textos antigos, bíblicos e extra-bíblicos.

\subsection{Os amuletos de Ketef Hinnom}

O núcleo da bênção aarônica (Nm 6,24-26) é o texto bíblico mais antigo que chegou até nós. Ele foi encontrado por G. Barkay ${ }^{17}$ escrito em duas lâminas

\footnotetext{
${ }^{17}$ BARKAY, G., The Priestly Benediction on Silver Plaques From Ketef Hinnom in Jerusalem, p. 143. Levine apontou que as lâminas com os textos eram compostas para acompanhar a pessoa também depois da morte no túmulo, querendo mostrar o desejo que o morto seria protegido e que
} 
de prata descobertas na Geena de Jerusalém em Ketef Hinnom, ao lado da igreja escocesa de Santo André, em escavações de 1979. As lâminas de prata configuravam dois pequenos amuletos em uma tumba do lado de fora da Antiga Jerusalém. Esses tipos de cavernas fúnebres eram comuns nos sécs. VII e VI a.C., mas a câmara 25 continha artefatos de diferentes épocas, o que dificulta a datação dos objetos. Em geral, costuma-se considerá-los provenientes do século VII a.C.

Os amuletos eram dois pequenos cilindros de prata quase pura imitando um rolo, sendo que o primeiro media 27 x $97 \mathrm{~mm}$ e o segundo, 11 x $39 \mathrm{~mm}$. As inscrições neles eram de aproximadamente $5 \times 3,5 \mathrm{~mm}$, feitas em paleo-hebraico. A conservação em preciosas placas de prata ressalta a importância dos objetos e da bênção neles contida, provavelmente para resguardar o falecido no mundo dos mortos. A descoberta foi reavaliada pelo próprio Barkay, ${ }^{18}$ o qual manteve as seguintes conclusões: são amuletos usados junto ao indivíduo para proteger do mal; são datados de um período pré-exílico; contêm o mais antigo retrato de um texto bíblico.

O texto escrito nos amuletos é representado no quadro abaixo de forma reconstruída, sendo que os colchetes mostram o texto provavelmente original. Nas duas primeiras colunas, está o conteúdo do amuleto 1 e 2 de Ketef Hinnom; ${ }^{19}$ na terceira, o TM de Nm 6,24-26 sem os sinais vocálicos, para facilitar a comparação.

\begin{tabular}{|c|c|c|}
\hline Amuleto 1 & Amuleto 2 & Nm 6,24-26 (TM) \\
\hline יברך יהוה & יברך יהוה & יברכך יהוה \\
\hline ישמרך & [י[ישמרך & וישמרך \\
\hline יאר יה[י[ה & [יא]ר יהוה & יאר יהוה \\
\hline פניו [אל]יך & פנגיוי] & פניו אליך \\
\hline & & ויחנך ישא יהוה פניו אליך \\
\hline וישם לך ש[ל]ם & & וישם לך שלם \\
\hline
\end{tabular}

a divinidade o guardasse bem não só na sua vida sobre a terra, mas também na sua descida ao Sheol (LEVINE, B. A., Numbers 1-20, p. 242-243).

18 BARKAY, G. et al., The Chalenges of Ketef Hinnom Using Advanced Technologies to Reclaim the Earliest Biblical Texts and Their Context, p. 41-68. A datação colocada no séc. VII a.C. ou início do VI a.C. é geralmente bem aceita, especialmente a partir da análise da sintaxe em comparação com as descobertas em Láquis. Ainda assim, há vozes discordantes, como a proposta de N. Na'aman (NA'AMAN, N., A new appraisal of the silver amulets from Ketef Hinnom), o qual propõe uma datação no período do Segundo Templo, próximo à sua construção. ${ }^{19}$ BARKAY, G., The Priestly Benediction on Silver Plaques From Ketef Hinnom in Jerusalem, p. 143. 
Os dois amuletos contêm uma versão reduzida da oração. Há uma pequena diferença quanto à primeira palavra da bênção de Números, aparecendo como יברך, sem o sufixo de objeto presente no TM, provavelmente representando uma sintaxe antiga simplificada. Nesse segundo caso, o sufixo de וישמרך teria efeito também no primeiro verbo, como acontece em Ex 13,13; 34,20 ; Os $6,1 .^{20}$

A mudança mais significativa é em relação à omissão de הנוה פניו אליך nos dois amuletos. É comum encontrar explicações que defendem que o texto de Números era a base para o texto dos objetos e, por um erro de haplografia, parte do texto teria sido obliterada. Assim, o artífice dos amuletos teria saltado o olhar do primeiro אליך para o segundo, omitindo o texto entre eles. Outros preferem defender que se trata de uma versão resumida da bênção em virtude do tamanho reduzido do objeto. ${ }^{21}$

A opção mais provável é que o texto de Números representa uma ampliação da versão menor, como defendeu Roesel. ${ }^{22}$ Essa proposta é assumida a partir da lógica construída pelo tecido verbal da bênção. Os dois primeiros verbos são a base na qual a oração dos amuletos é desenvolvida, abençoar (a) e guardar (b), ambos amplificados em fazer resplandecer seu rosto $\left(\mathrm{a}^{1}\right)$ e dar a paz $\left(b^{1}\right)$. Nesse primeiro formato, o segundo estíquio garante a projeção do primeiro em sentido menos material, em formato de paralelismo. O texto de Números provavelmente quis manter o final desejando o שלם , de forma que ampliou o texto internamente, inserindo a ideia de ser bondoso ${ }^{23}\left(\mathrm{a}^{2}\right)$ e dirigir o rosto em direção $a\left(\mathrm{~b}^{2}\right)$, formando o seguinte modelo simétrico: $\mathrm{a}+\mathrm{b} ; \mathrm{a}^{1}+\mathrm{a}^{2} ; \mathrm{b}^{2}+\mathrm{b}^{1}$.

\subsection{Textos bíblicos}

Encontramos no AT vários textos que tratam de bênçãos. Eclesiástico

\footnotetext{
${ }^{20}$ LEVINE, B. A., Numbers 1-20, p. 239-240.

${ }^{21}$ Para a primeira opção, ver LEVINE, B. A., Numbers 1-20, p. 240; para a segunda, MILGROM, J., Numbers, p. 361.

${ }^{22}$ ROESEL, H., Zur Formelierung des aaronitischen Segens auf den Amuletten von Ketef Hinnom, p. 30-36. A proposta do autor é ampliada e discutida em: LEVINE, B. A., Numbers 1-20, p. 241-242.

${ }^{23}$ A expressão é idiomática e ocorre frequentemente no saltério ( $\mathrm{Sl} 4,7 ; 31,17 ; 44,4 ; 80,4.8 .20$; 89,16 etc.) como uma figura de linguagem para indicar benevolência e favor (NGUYEN, D. A. N., Numeri, p. 108), portanto, em um campo semântico próximo ao "ser bondoso" (v. 25b), com o qual é colocado em paralelo.
} 
aponta que havia uma fórmula para abençoar o povo no contexto do segundo templo (Eclo 50,20). Deuteronômio mostra que a bênção era parte das funções sacerdotais (Dt 21,5) e envolvia toda a tribo de Levi (Dt 10,8). Outras fórmulas ligadas à bênção estão em Gn 12,1-3; 27,27-29; 48,15-28; 49,25s; Lv 26,4-13. Há modelos de bênção no formato de cumprimento em Rt 2,4; Jz 6,12;1Sm 17,37; 20,13; Gn 43,29; 2Sm 12,22, ou seja, fora de contextos litúrgicos, de forma que elas podem não ter se originado nesse Sitz im Leben. Analisando esses textos, Levine ${ }^{24}$ defende que as saudações pessoais usadas para se dirigir a reis ou pessoas do cotidiano foram levadas para a liturgia oficial do templo, endereçadas a Deus, ainda que o caminho contrário seja possível.

Ainda que o tema da bênção seja muito frequente e esteja entre os mais caros do AT, como a aliança, a santidade, a promessa, a justiça etc., não se encontra em nenhum outro livro veterotestamentário a mesma fórmula de bênção de Nm 6,22-27. Como demonstrado no quadro a seguir, excertos de $\mathrm{Nm}$ 6,34-25 aparecem de maneira fragmentada especialmente na literatura sálmica, mas nunca a fórmula em sua totalidade. Esses textos provavelmente dependem literariamente de Nm 6,22-27. Para facilitar a identificação dos textos semelhantes, destacamos na tradução as partes próximas da bênção aarônica.

\begin{tabular}{|c|c|}
\hline Texto hebraico & Tradução \\
\hline 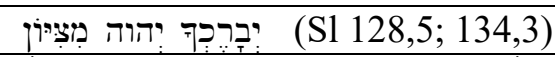 & "YHWH te abençoe desde Sião...". \\
\hline 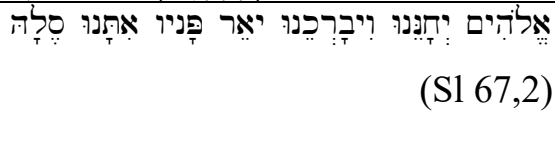 & $\begin{array}{l}\text { "Deus? seja benévolo e nos } \\
\text { abençoe, faça resplandecer o seu } \\
\text { rosto sobre nós". }\end{array}$ \\
\hline 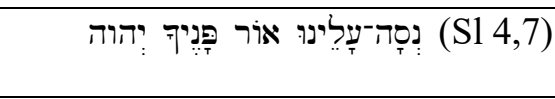 & $\begin{array}{l}\text { "Faça (resplandecer) sobre nós a } \\
\text { luz do teu rosto, } Y H W H " \text {. }\end{array}$ \\
\hline 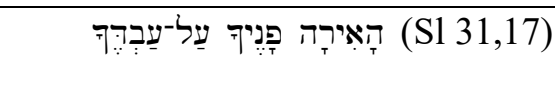 & $\begin{array}{l}\text { "Faça resplandecer o teu rosto } \\
\text { sobre o teu servo". }\end{array}$ \\
\hline 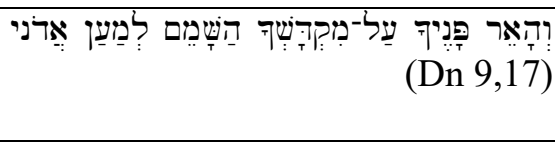 & $\begin{array}{l}\text { "E faça resplandecer o teu rosto } \\
\text { sobre o teu santuário devastado, por } \\
\text { amor de Tu mesmo, Senhor!". }\end{array}$ \\
\hline
\end{tabular}

Nesses salmos, repete-se temas teológicos da bênção aarônica, especialmente desejando que "o Senhor abençoe", mostrando a natureza divina

${ }^{24}$ LEVINE, B. A., Numbers 1-20, p. 238. 
da bênção aos seres humanos e pedindo que o Senhor volte e faça resplandecer o seu rosto em direção a pessoas, comunidade, cidade, santuário etc. Refletindo a ideia da guarda/proteção de YHWH (Nm 6,24b), o Sl 121,3a.4c.5a.7a.8a

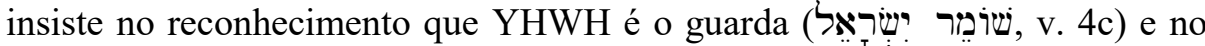

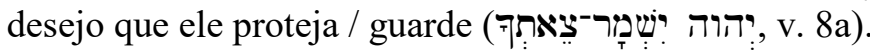

\subsection{Manuscritos do Mar Morto}

Há poucos manuscritos do Mar Morto que trazem o texto de Números (1QpaleoLev-Num, 1QM, 2QNum, 4QNum) e em nenhum deles o texto de Nm 6,22-27 é retratado. Por outro lado, encontram-se orações seguramente dependentes da antiga bênção da Torá em outras partes: (a) dentre os Manuscritos da Gruta 1, encontramos alguns fragmentos da Regra da Comunidade (1QS), dos mais significativos, parte da Coleção de Bênçãos. É um grupo de orações de estrutura simples: um texto em prosa anuncia o destinatário da invocação e segue-se, em poesia, a respectiva oração. Parte de 1QSb II,22-28 e 1QSb III,1-3 possui semelhança com a bênção aarônica; (b) também na coleção de hinos encontramos aproximações, especialmente em 11QSN, 11QHymns ${ }^{\mathrm{a}}\left(2 \mathrm{Q} 285\left[4 \mathrm{QM}^{\mathrm{g}}\right]\right)$. Apresentamos no quadro a seguir a tradução desses três fragmentos de bênçãos qumrânicas cujas semelhanças vocabulares e paralelos com Nm 6,22-27 encontram-se em itálico, com o texto hebraico de Qumran entre parênteses..$^{25}$ As lacunas no texto são indicadas com "(...)" e as supressões para os fins deste artigo, com "[...]".

\begin{tabular}{|c|c|}
\hline 1QSb II,22-28 & 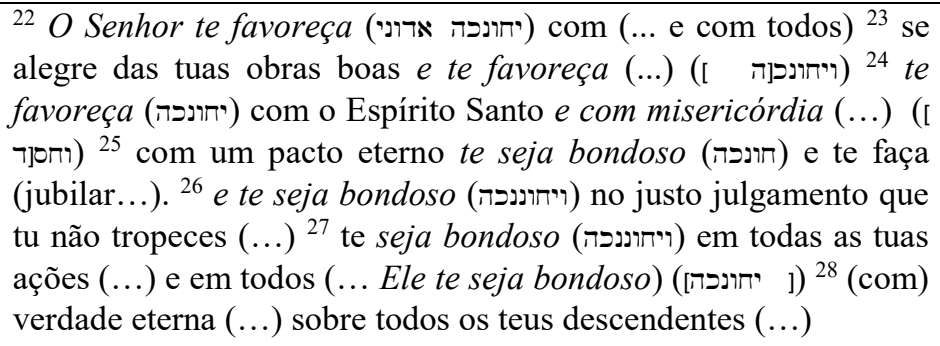 \\
\hline
\end{tabular}

${ }^{25}$ A partir da proposta de Martinez e Tigchelaar (The Dead Sea Scrolls, p. 104, 1210-1211), com o apoio do estudo de Moraldi (MORALDI, L., I Manoscritti di Qumran, p. 199-200), especialmente em relação à reconstrução das lacunas do texto fragmentado. 


\begin{tabular}{|c|c|}
\hline 1QSb III,1-3 & 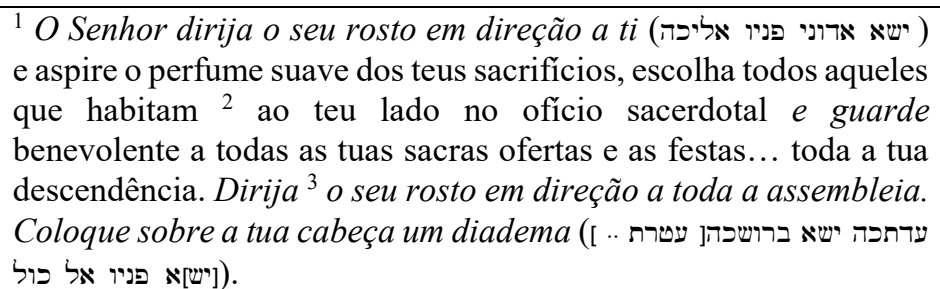 \\
\hline $\begin{array}{l}\text { 11QSM, } \\
11 \mathrm{QHymns}{ }^{\mathrm{a}} \\
\text { Frag. } 1 \mathrm{col} . \mathrm{II} \\
(=4 \mathrm{Q} 285 \mathrm{I})\end{array}$ & 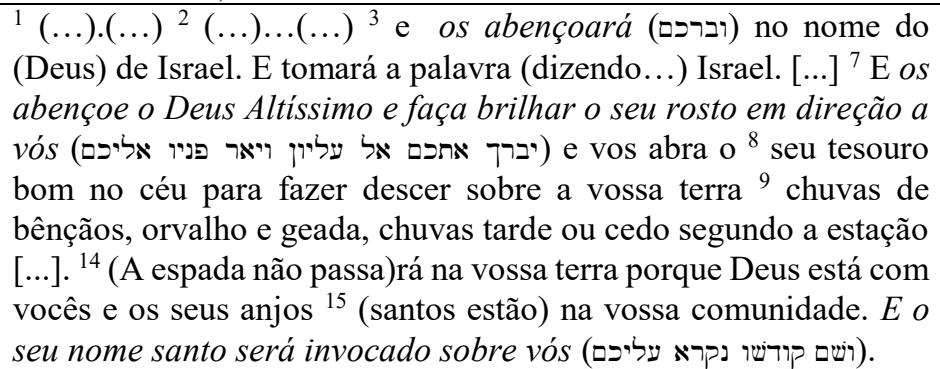 \\
\hline
\end{tabular}

Algumas diferenças de vocabulário, morfologia e sintaxe representam mudanças no hebraico da época, por exemplo: o tetragrama já não se pronunciava mais e no seu lugar se escrevia אדוני; o sufixo de $2 \mathrm{~ms}$ ๆ aparecia como (1QSb II,22), uma variação em relação ao TM; outra mudança é a de כּל (absoluto) ou כָּ (1QSb III,3). Percebem-se também semelhanças de estilo e teologia: o sujeito da bênção é sempre Deus, a quem se pede a bondade/favor (Nm 6,25b) e que dirija o seu rosto em direção àqueles que a recebem $(\mathrm{Nm} 6,26)$. No final da citação da coleção de hinos, como uma conclusão, encontra-se uma frase semelhante àquela de $\mathrm{Nm} 6,27$, na qual o nome santo é invocado sobre a comunidade. Também as duas primeiras citações têm como destinatário a segunda pessoa do singular, como um sujeito coletivo que inclui toda a comunidade, seguindo o estilo da bênção aarônica.

As semelhanças vocabulares, temáticas e fraseológicas destacadas no quadro acima deixam entrever que a comunidade de Qumran conhecia a antiga bênção aarônica na versão de Números, já que o testemunho arqueológico de Ketef Hinnom e o conhecimento da Torá em Qumran atestam sua antiguidade e familiaridade. Pode ser que a versão de Números tenha sido uma base adaptada para ficar mais conforme à teologia da comunidade ou que serviu de inspiração mais geral para a construção de outras bênçãos. Por exemplo: no lugar dos "filhos de Israel" (Nm 6,23b.27a) vem nominada "toda a assembleia" (1QSb III,3), 
aqueles que seguem os preceitos do Senhor. Os sacerdotes aaronitas, ministros da bênção em Nm 6,22-27, vêm substituídos em Qumran pelo "Sábio".

\section{Estrutura de Nm 6,22-27}

Como estudo comparativo da bênção aarônica em relação a textos bíblicos e não bíblicos, ficou claro que a forma e o conteúdo do texto são ímpares em relação às suas ocorrências semelhantes. Nosso estudo aqui se concentrará na forma, demonstrando como a estrutura de Nm 6,22-27 foi construída a fim de valorizar sua mensagem teológica.

A sinalização massorética do texto hebraico ajuda a dividir a bênção aarônica em unidades menores: a primeira configura a introdução à bênção (vv. 22-23); os três versículos seguintes correspondem ao corpo com o conteúdo da bênção (vv. 24-26); no fim, o último versículo forma a conclusão da bênção (v. 27). Assim, o conteúdo da oração é emoldurado. No início está a constante

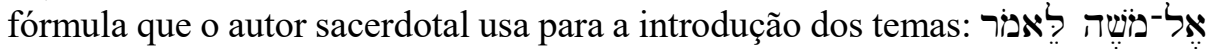

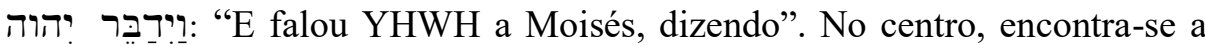
bênção propriamente dita, ocupando o espaço mais importante, porque se coloca ao centro aquilo que é importante, enquanto aquilo que é secundário vêm colocado em um ângulo, às margens. $O$ fechamento da moldura traz uma particular fórmula de conclusão, garantindo que a bênção, vinda de Deus, representa a garantia de sua presença junto aos israelitas. A conclusão traz a

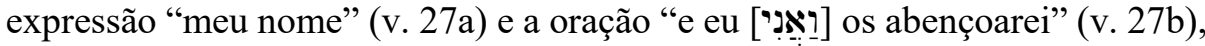
com o enfático pronome pessoal de primeira pessoa, acentuando que o dono da ação é YHWH.

As faces da moldura são colocadas, portanto em um claro paralelismo, de forma que o v. 27 realiza aquilo que foi anunciado nos vv. 22-23. No v. 23

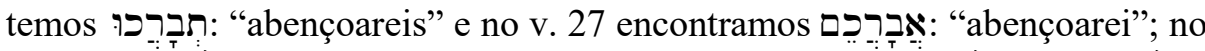

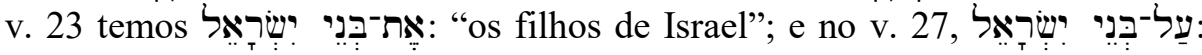
"sobre os filhos de Israel". Ou seja, o mandato que foi ordenado na introdução, desenvolvido nos vv. 24-26, é sublinhado mais uma vez na conclusão. Além do mais, a primeira e a última expressão do poema têm exatamente 7 sílabas,

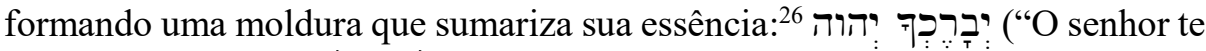

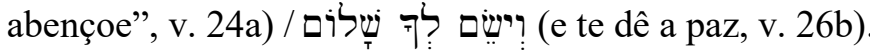

${ }^{26}$ MILGROM, J., Numbers, p. 51. 
A estrutura da bênção propriamente dita (Nm 6,24-26) foi organizada com muito esmero. Os três versículos são paralelos entre eles, tanto na forma como no conteúdo. Cada versículo da bênção é constituído de uma primeira oração formada por um verbo no jussivo, tendo o tetragrama como sujeito, seguida por uma segunda oração formada por outro verbo no jussivo unido ao primeiro pela conjunção ?. Dessa forma, a segunda oração pressupõe sujeito. Nos vv. 25-26, acrescenta-se um complemento.

Esse paralelismo foi composto em uma simples e elegante estrutura progressiva, como ilustrado no quadro a seguir. O primeiro versículo (v. 24) é formado por três palavras hebraicas, o segundo (v. 25) contém cinco palavras e, no terceiro (v. 26), encontramos sete palavras. A mesma progressão é notada quanto ao número de sílabas e de consoantes, construindo um efeito visual e sonoro agradável.

\begin{tabular}{|c|c|c|c|c|}
\hline Versículo & Texto hebraico & $\begin{array}{c}\text { Número de } \\
\text { palavras }\end{array}$ & $\begin{array}{c}\begin{array}{c}\text { Número de } \\
\text { sílabas }\end{array} \\
\end{array}$ & $\begin{array}{l}\text { Número de } \\
\text { consoantes }\end{array}$ \\
\hline 24 & יברכך יהוה וישמרך & 3 & 12 & 15 \\
\hline 25 & יאר יהוה פניו אליך ויחניך & 5 & 14 & 20 \\
\hline 26 & ישא יהוה פניו אליך וישם לך שלום & 7 & 16 & 25 \\
\hline
\end{tabular}

O formato não é assimétrico, como defendia Noth, mas de uma simetria ascendente, cuja estrutura rítmica se conecta bem com a recitação oral e facilita a memorização. ${ }^{27} \mathrm{O}$ formato crescente do poema, representado pelas proporções de palavras, sílabas e consoantes, tem uma função estética no imaginário do ouvinte e do leitor: espelha o derramamento da bênção a partir do sacerdote, espalhando-se no povo. ${ }^{28}$

A primeira parte de cada linha da bênção invoca o movimento de Deus em direção a seu povo (bênção, resplandecimento e dirigir o rosto). A segunda linha mostra o resultado de sua atividade em favor dos israelitas (proteção, bondade e garantia de paz). Segundo Milgrom, ${ }^{29}$ o waw transicional pode

${ }^{27}$ KNIERIM, R. P.; COATS, G. W., Numbers, p. 93.; NGUYEN, D. A. N., Numeri, p. 108.

${ }^{28}$ OLSON, D. T., Numbers, p. 41.

29 MILGROM, J., Numbers, p. 51. Levine (LEVINE, B. A., Numbers 1-20, p. 236-237) apresentou uma série de estudos comparativos de textos do Antigo Oriente Próximo para determinar que os binômios formados pelos verbos nos três estíquios frequentementemente estão colocados em paralelismos em textos acádicos, ugaríticos e em cartas aramaicas dos 
indicar consequência, de forma que o primeiro verbo resulte no segundo, formando três ações principais. Contudo, a estrutura não imita uma hendíade, mas reforça o sentido próprio dos verbos das segundas orações.

$\mathrm{O}$ texto da bênção está em segunda pessoa singular, quando se esperava o plural. Contudo, esse recurso retórico "aproxima a bênção ao estilo e à índole dos Salmos, que consideram frequentemente a coletividade como uma realidade única e indivisível, aquela que tem יהוה somente por origem". ${ }^{30}$ Além do mais, o endereço da bênção no singular mostra que podia ser usada tanto na liturgia quanto individualmente, já que o "tu" é bem acomodado aos dois casos. "Parece que era normal nominar em segunda pessoa na liturgia e na pregação: isso demonstra que o povo é uma unidade, uma pessoa moral, o sócio da aliança; porém também que cada um dos seus membros esteja implicado nessa". ${ }^{31}$ Encontramos os israelitas identificados no singular em textos como o Decálogo (Ex 20,2-17; Dt 5,6-18) e em outras fórmulas de bênção (Dt 28,1-14).

Para enfatizar a origem divina da bênção, o texto traz a tríplice repetição do Tetragrama como elemento estruturante da fórmula. Assim, mostra que a função dos sacerdotes é ser somente um canal da bênção, a qual tem origem no Senhor. De fato, o v. 27 funciona como uma admoestação: os sacerdotes são responsáveis por submeter Israel a YHWH, mas ele é quem dá a bênção. Assim, a oração se destaca e é colocada em contraste com textos que mostram a bênção sendo dada pelos sacerdotes, como Sl 118,26. Números é taxativo: o sacerdote é somente mediador.

A dimensão superlativa formada pela tríplice repetição de YHWH parece ter o efeito indicado na conclusão: o nome reiterado é depositado sobre o povo. Noth $^{32}$ mostra que a tríplice repetição do sujeito não representa um uso gramatical necessário em si mesmo; outros textos trazem a bênção impessoal, na qual YHWH aparece como sujeito implícito, definido pelo contexto, como no S1 118,26. De fato, a menção de YHWH como sujeito em 24a já daria sentido às orações jussivas subsequentes. Sendo assim, a construção claramente valoriza YHWH como doador da bênção.

aquemênidas. Isso fortalece a dimensão redacional da benção aarônica e a intencionalidade da elaboração de sua estrutura.

${ }^{30}$ BERNINI, G., Il Libro dei Numeri, p. 77, tradução nossa.

${ }^{31}$ BUIS, P., El libro de los Números, p. 32, tradução nossa.

${ }^{32}$ NOTH, M., Numbers, p. 58. 
Como sinalizamos na crítica textual, houve uma tentativa de mudança da estrutura da perícope de Nm 6,22-27 no texto grego original. No textus Graecus originalis o conteúdo do versículo 27 foi deslocado para o fím do versículo 23 . Assim, esta parte deslocada não configurava mais a conclusão da bênção, como no TM, mas passou a fazer parte da introdução. É difícil reconstruir os motivos para tal alteração. Como Nm 7 mostra uma digressão na forma de um apêndice antes de levantar o acampamento, é possível que os tradutores gregos preferiram encerrar a preparação para a marcha dos caps. 1-6 com a bênção saindo da boca de Deus. O impacto narrativo é inegável, já que se substitui a frase explicativa do v. 27 para o resultado impactante da ação de Deus; a paz! A fórmula de bênção constitui assim um paradigma pelo qual o leitor irá interpretar todas as narrativas de conflito e murmuração que povoam os caps. 11-21 do livro, entremeadas pelas leis que tentam salvaguardar a santidade do acampamento e a manutenção da bênção e da paz. Apesar de tentadora, a proposta parece desconhecer o arranjo tão bem arquitetado no formato de uma moldura, que dá sentido à unidade, de forma que a alteração da estrutura do TM a partir do texto grego mais antigo é, sem dúvida, a opção menos preferível. ${ }^{33}$

\section{Conclusão}

Nosso estudo sobre a bênção aarônica ofereceu uma discussão em dois caminhos: primeiro, em relação à colocação literária do texto, então, sobre sua estrutura. Nossa proposta sobre o Sitz in der Literatur foi influenciada particularmente pelos estudos narrativos de Números, de forma que a oração foi entendida como uma conclusão lógica dos caps. 1-5, os quais proporcionam uma visão triunfante da organização cúltico-militar dos israelitas no contexto da preparação para a marcha rumo a Canaã. Trata-se de uma garantia da presença de YHWH junto a seu povo a partir da mediação sacerdotal.

O estudo das fórmulas bíblicas e extra-bíblicas semelhantes a Nm 6,2227 permitiu, em primeiro lugar, afirmar que a benção é muito antiga e foi bem conservada nos amuletos de Ketef Hinnom. Sendo assim, a versão consignada em Números deve ter inspirado outros textos bíblicos semelhantes, particularmente, dos salmos. Contudo, a estrutura presente no quarto livro do Pentateuco é particular e notável. As técnicas de emolduramento, paralelismos

${ }^{33}$ MONA, D. M. N., As múltiplas faces da bênção sacerdotal, p. 95. 
e acomodação gradativa de palavras, sílabas e consoantes dão ao texto um poderoso efeito litúrgico e popular. Ainda que a versão grega antiga proponha uma alteração dessa estrutura, nosso estudo destacou que a harmonia da versão final do TM é inegável e irretocável.

Sendo assim, a bênção aarônica ganha um espaço particular no contexto das bênçãos israelitas. Isso pode ser percebido na tradição judaica posterior: segundo a Mishná Megillah IV, 10, a bênção aarônica não devia ser traduzida; e podia ser pronunciada só em hebraico. ${ }^{34}$ De fato, alguns targumim contêm só o texto hebraico. O Targûm Jo ofereceu uma inovação: fez seguir cada frase da bênção do texto hebraico com uma paráfrase aramaica.

No Novo Testamento (NT) o tema da bênção é muito caro a Jesus, que abençoou as crianças (Mc 10,16), os apóstolos (Lc 24,50), o pão, na ocasião da multiplicação dos pães (Mc 6,14; 8,7) e na última ceia (Mc 14,22; Mt 26,26). O apóstolo Paulo se refere seguidamente ao tema da bênção nas suas cartas (Rm 1,$7 ; 1,11 ; 1,25 ; 1$ Cor 4,$12 ; 16,16 ; 2$ Cor 1,$3 ; 11,31 ;$ Gl 3,8; 6,16; Ef 1,3). Ainda assim, o NT nunca utilizou diretamente o texto de Nm 6,22-27. Porém, ao menos em um lugar, um silêncio eloquente desperta nossa atenção: quando o início do Evangelho de Lucas nos coloca no Templo observando Zacarias dramaticamente ficar emudecido (Lc 1,5-22), percebemos que a liturgia que estava celebrando ficou incompleta... Faltou justamente que o sacerdote proferisse a bênção final, a bênção aarônica, que dá ali lugar a um novo anúncio: o Messias chegou e o nome de Deus está definitivamente sobre seu povo.

\section{Referências bibliográficas}

ALONSO SCHÖKEL, L. Dicionário bíblico hebraico-português. São Paulo: Paulus, 1997.

ASHLEY, T. R. The Book of Numbers. Grand Rapids: William B. Eerdmans Publishing Company, 1992.

BARKAY, G. The Priestly Benediction on Silver Plaques From Ketef Hinnom in Jerusalem. Tel Aviv: Journal of The Institute of Archaeology of Tel Aviv University, v. 19, p. 139-192, 1992.

${ }^{34}$ FERNÁNDEZ, M. P., Midrás Sifre Números, p. 147. 
BARKAY, G.; LUNDBERG, M. J.; VAUGHN, A. G.; ZUCKERMAN, B.; ZUCKERMAN, K. The Chalenges of Ketef Hinnom Using Advanced Technologies to Reclaim the Earliest Biblical Texts and Their Context. Near Eastern Archaeology, v. 66, n. 4, p. 161-171, 2003.

BERNINI, G. Il libro dei Numeri. Torino: Marietti, 1971.

BUDD, P. J. Numbers. Texas: General Editors, 1984.

BUIS, P. El libro de los Números. Estella: Verbo Divino, 1996.

CATENASSI, F. Z. Análise narrativa da transgressão em Cades (Números 13-14): função literária na unidade e na composição do Pentateuco. Curitiba, 2018, 325p. Tese. Escola de Educação e Humanidades, Pontifícia Universidade Católica do Paraná.

CATENASSI, F. Z. Reclamando "de barriga cheia": o maná e as codornizes em Qibrot-hatta'awah (Nm 11,4-35). Estudos Bíblicos, v. 35, n. 137, p. 11-24, jan./mar. 2018.

ELLIGER, K.; RUDOLPH, W. (Eds.). Biblia Hebraica Stuttgartensia. 5.ed. Stuttgart: Deutsche Bibelgesellschaft; Barueri: Sociedade Bíblica do Brasil, 1990.

FERNÁNDEZ, M. P. Midrás Sifre Números. Valencia: Intitución San Jerónimo, 1989.

GRAY, G. B. A critical and exegetical commentary on Numbers. Endinburgh: T \& T Clark, 1976.

KNIERIM, R. P.; COATS, G. W. Numbers. Grand Rapids: William B. Eerdmans Publishing Company, 2005.

LAMADRID, A. G. Números: texto y commentario. Madrid: Sígueme, 1990.

LEVINE, B. A. Numbers 1-20: a new translation with introduction and commentari. London: Yale University Press, 2008.

MANICARDI, L. La benedizione sacerdotale, Nm 6,22-27. Parola Spirito e Vita, v. 21, p. 61-82, 1990. 
MARTÍNEZ, F. G.; TIGCHELAAR, E. J. C. The Dead Sea Scrolls: study edition. Leiden: Brill; Grand Rapids: William B. Eerdmans Publishing Company, 2000. 2 v.

MILGROM, J. Numbers. New York: The Jewish Publication Society, 1980.

MONA, D. M. N. As múltiplas faces da bênção sacerdotal. Pesquisas em Teologia, v. 1, n. 1, p. 92-107, 2018. Disponível em: <http://periodicos.pucrio.br/index.php/pesquisasemteologia/article/view/684>. Acesso em: 12 jun. 2021.

MORALDI, L. I Manoscritti di Qumran. Torino: TEA, 1971.

NA'AMAN, N. A new appraisal of the silver amulets from Ketef Hinnom. Israel exploration Journal, v. 61, n. 2, p. 184-195, 2011.

NGUYEN, D. A. N. Numeri: introduzione, traduzione e commento. Milano: San Paolo, 2017.

NOTH, M. Numbers: a commentary. Philadelphia: The Westminster Press, 1968.

NOVA Vulgata Bibliorum Sacrorum. Città del Vaticano: Libreria Editrice Vaticana, 1986.

OLSON, D. T. Numbers. Lousville: John Knox Press, 1996.

ORÍGENES. Omelie sui Numeri. Roma: Città Nuova Editrice, 2001.

ROESEL, H. Zur Formelierung des aaronitischen Segens auf den Amuletten von Ketef Hinnom. Biblische Notizen: Zeitschrift für Bibelwissenschaften und ihre Grenzgebiete, v. 35, p. 30-36, 1986.

SILVA, C. M. D. Metodologia de exegese bíblica. São Paulo: Paulinas, 2009.

VAULX, J. Les Nombres. Paris: J. Gabalda, 1972.

WEBER, R. (Ed.). Biblia Sacra iuxta Vulgatam versionem. 4.ed. Stuttgart: Deutsche Bibelgesellschaft, 1994.

WEVERS, J. W. (Ed.). Septuaginta: Vetus Testamentum Graece. Goettingen: Vandenhoeck \& Ruprecht, 1982. 
ISSN 2596-2922

DOI: 10.46859/PUCRio.Acad.ReBiblica.2596-2922.2021v2n4p285

Ildo Perondi

Doutor em Teologia pela Pontifícia Universidade Católica do Rio de Janeiro Docente no Programa de Pós-Graduação em Teologia da Pontifícia Universidade Católica do Paraná Curitiba / PR - Brasil E-mail: ildo.perondi@pucpr.br

Fabrizio Zandonadi Catenassi

Doutor em Teologia pela Pontifícia Universidade Católica do Paraná Docente no Programa de Pós-Graduação em Teologia da Pontifícia Universidade Católica do Paraná Curitiba / PR - Brasil E-mail: fabriziocatenassi@gmail.com

Recebido em: $12 / 10 / 2021$ Aprovado em: 02/12/2021 